Max-Planck-Institut für demografische Forschung

Max Planck Institute for Demographic Research

Doberaner Strasse 114 - D-18057 Rostock - GERMANY

Tel +49 (0) 3812081 - 0; Fax +49 (0) 3812081 - 202;

http://www.demogr.mpg.de

MPIDR WORKING PAPER WP 2002-038

AUGUST 2002

\title{
Structural Change and Occupational Attainment in Monterrey, Mexico
}

\author{
Patricio Solís (patricio@prc.utexas.edu) \\ Francesco C. Billari (billari@demogr.mpg.de)
}

(C) Copyright is held by the authors.

Working papers of the Max Planck Institute for Demographic Research receive only limited review. Views or opinions expressed in working papers are attributable to the authors and do not necessarily reflect those of the Institute. 


\title{
Structural Change and Occupational Attainment in Monterrey, Mexico*
}

\author{
Patricio Solís \\ Population Research Center \\ University of Texas at Austin
}

\author{
Francesco C. Billari
}

Research Group on the Demography of Early Adulthood Max Planck Institute for Demographic Research

\begin{abstract}
Latin American societies have experienced profound economic transformations in recent years. Yet, little is known about the effects of these transformations on occupational attainment and mobility. We study these effects in Monterrey, the third largest city of Mexico. We analyze two stages of men's process of occupational attainment: the entry into the labor force and subsequent job shifts. Despite short-term negative effects in the 1980s, Monterrey's labor market upgrading has continued, facilitating upward mobility. However, class of origin remains an important determinant of attainment, labor-market segmentation imposes barriers to mobility, and wages in non-manual occupations have decreased, thus imposing particular characteristics to occupational attainment.
\end{abstract}

\footnotetext{
* Direct correspondence to Patricio Solís, Population Research Center, University of Texas at Austin, 1800 MAI, Austin, TX 78712, or e-mail to patricio@prc.utexas.edu. Support for this research was provided by The Population Council, the Andrew W. Mellon Foundation, the Population Research Center of the University of Texas at Austin, and the Max Planck Institute for Demographic Research.
} 


\section{Introduction}

In the past half-century, Mexico has experienced a number of noteworthy economic, social, and demographic changes. During the 1950s, 1960s, and 1970s, fast industrialization and urbanization contributed to radically change the social landscape of the country. In the 1980s, the depletion of the "inward-looking" model of growth derived in a profound economic recession, the increase in poverty, and the overall reduction of welfare levels. Finally, during the last decade of the past century, after profound structural transformations aimed at opening the domestic economy to external markets, economic growth renewed, although with reduced rates than the ones observed before the "lost decade" of the 1980s.

For a long time, research on the social consequences of these transformations has focused on the evolution of the distribution of income and poverty levels (Boltvinik 2001; Cortés 2001; World Bank et al 2001), as well as on the active response of urban families to economic strain, particularly during the crisis years of the 1980s, through the so-called "survival strategies" (González de la Rocha 1994; Selby, Murphy, and Lorenzen 1990; Tuirán 1993). Less attention has been paid to the consequences of these transformations on social stratification and, more specifically, occupational mobility patterns. The shortage of recent research is more notorious because it contrasts with the considerable interest in the topic during the 1960s and 1970s (See for example: Balán, Browning and Jelin (1973) and Muñoz, Stern and Oliveira (1977)), when several studies documented the high rates of upward structural mobility and relative openness of the occupational structure characterizing Mexican cities during the peak of the "substitution of imports" period of growth of the national economy ${ }^{1}$. Unfortunately, little is known about the changes that these occupational mobility regimes may have experienced after the economic transformations of the 1980s and 1990s.

In this article, we aim at advancing the comprehension of these changes by studying mobility patterns in Monterrey, the third largest city of Mexico and the leading industrial city of the nation. We examine two different stages of the process of occupational attainment (Blau and Duncan 1967): the position of entry into the labor

\footnotetext{
${ }^{1}$ These trends were typical not only of Mexican cities, but also of most Latin American cities during the decades of accelerated economic growth after World War II and before the 1980s. Perhaps the first empirical account of these transformations is given by Germani (1959) for the case of Argentina.
} 
force and subsequent job mobility. Our interest is not only on the analysis of changes over time in mobility rates, but also on the characteristics of the occupational attainment process in urban Mexico. More specifically, we look at the effects of men's class of origin and education, as well as at the impact of other structural factors such as the insertion in the formal or informal economy. Our purpose is twofold. First, we contribute to the growing debate about the social consequences of economic restructuring and liberalization in Mexico and Latin America. Second, we broaden the knowledge of the characterization of contemporary mobility regimes in the region, in light of both the structural transformations mentioned above and the particular institutional settings that separate Mexican urban labor markets from their counterparts in developed countries.

Traditionally, the overall patterns of mobility observed in a given society - and their changes over time - have been conceived as being the result of broad structural forces, such as economic restructuring, technological advancements, and demographic change (Erikson and Goldthorpe 1992; Featherman and Hauser 1978). More recently, researchers have turned their attention on the interaction between these structural forces and institutional and organizational settings, such as welfare policies, the educational system, and the organization of labor markets, in the generation of specific "mobility regimes" (DiPrete et al 1997; Esping-Andersen 1993; Kerckhoff 1995; Mayer 2001). However, so far this research has focused on industrialized societies. In order to extend our understanding to developing societies, it is necessary first to review their most relevant social and economic transformations in recent decades, and the way in which these structural changes may have interacted with specific institutional and organizational features to alter mobility patterns. In the following two sections we illustrate the case of Monterrey, and we derive specific hypotheses about the characteristics of its mobility patterns. The remainder of the article is organized as follows. In Section 4 we introduce our data set, the variables included in the analysis, as well as our analytical strategy. Then we present our results for the initial entry into the labor force (Section 5) and for job shifts (Section 6). Finally, we discuss our most significant conclusions as well as directions for further research. 


\section{Structural Change and Labor Markets in Monterrey}

Located only 140 miles south of the United States border, Monterrey is the leading economic pole of north Mexico. With more than 3.2 million residents in the year 2000, the city's population is only exceeded by those of Mexico City and Guadalajara, the other two large metropolitan areas of the country. The industrial development of Monterrey dates back to the end of the $19^{\text {th }}$ century, with the opening of a brewing factory and the first modern steel mill in Latin America (Cerutti 1992). The expansion of manufacturing activities in the city accelerated between the 1940s and 1970s, under the favorable conditions created by protectionist policies and high rates of economic growth, during the so called "substitution of imports" period of the Mexican economy. However, by the beginning of the 1980s this model of economic growth entered in a profound structural crisis, prompted by the high cost of the external debt and the inability of the State to maintain its subsidizing role in industrial growth. Eventually, the "debt crisis" gave way to structural reforms based on liberalization policies. Such reforms led to the virtual end of protectionist policies, the withdrawal of the state as a direct agent in economic activities, the opening of the commodities and financial markets, and the promotion of external investment in manufacturing activities.

Monterrey's largest manufacturing conglomerates were extremely vulnerable to the debt crisis and further liberalization of the economy (Pozos Ponce 1996), although their accumulated experience, their adaptation skills, and also the assistance received from the federal government, helped them to eventually restructure their activities and adapt to the new circumstances. To illustrate the magnitude of the crisis, during the three years between 1980 and 1983, Alfa and Visa, two of the most important conglomerates of the city (and the country as a whole) fired 17,000 and 11,000 workers, respectively. Only three years later, in 1996, Fundidora Monterrey, the historical steel mill, shut down, creating 11,000 direct layoffs and the lost of other several thousands of jobs in small shops with direct linkages to the mill. In 1983, the unemployment rate reached $9.8 \%$, the highest level at the time in urban Mexico (Pozas 2002) and a notably high figure if we take into account that in Mexico there are virtually no welfare benefits for unemployed workers (Martin 2000). 
The financial crisis forced Monterrey firms to modify their strategies, and this in turn contributed to reshape local labor markets during the 1980s and 1990s. To illustrate the extent of this transformation, in Table 1 we show the distribution of Monterrey's labor force by industry between 1966 and 1998. The impact of economic restructuring on the labor force had two characteristics, intimately connected with each other. First, during the crisis years of the first half of the 1980s, many workers were forced out from manufacturing activities. The creation of new jobs in manufacturing also came to a temporary halt, while industrial conglomerates as well as other medium- and small-sized manufacturing firms struggled to survive. The reduction in the proportion of workers in manufacturing activities from $36.5 \%$ in 1978 to $31.1 \%$ in 1983 and $27.3 \%$ in 1987 illustrates the extent of these changes.

\{Table 1 about here

Second, service activities and, to a lesser extent, commerce, have grown and eventually occupied the place of manufacturing as the dominant economic sector. The proportion of workers in service activities had only shown a moderate increase between $1966(25.1 \%)$ and 1978 (31.7\%), but its growth accelerated to 39.0\% in the following nine years. Commerce activities also increased their share in the labor market, from $16.0 \%$ in 1983 to $22.5 \%$ in 1998 . The increase in service and commerce occupations was associated to several economic transformations, such as the continuing expansion of service activities linked to demographic growth, the increase in financial activities and producer services during the 1990s, and the growth of petit and informal commerce as "refugee" activities during the recession years. In any case, what these transformations show is that the transition from secondary to tertiary activities in Monterrey was not halted, and may even have been accelerated, by the debt crisis and subsequent liberalization during the 1990s and 2000s.

In the 1990s the largest conglomerates in Monterrey "successfully" adapted to the new circumstances and experienced a second period of economic growth, only 
temporarily interrupted by the financial crisis of 1995 . However, there are several reasons to think that workers were not equally benefited from these changes. Indeed, one of the reactions to the structural crisis of the 1980s has been the instrumentation of a very restrictive policy in wages, instrumented by the private sector in coordination with the federal government (Lustig 1998). In practice, this policy has translated into a dramatic reduction of real wages, particularly during the 1980s and the financial crisis of 19941995. Even in 2000, wages have not recovered to the levels reached at the end of the 1970s. There are also indications of an increasing precariousness in work conditions, associated both to the increase in the proportion of workers participating in the "informal sector" and the worsening of job conditions within "formal" firms.

It is more difficult to obtain a clear picture of the effects of these transformations on occupational mobility. In the 1960s, during the peak of the substitution of imports period, occupational mobility was driven by the structural expansion of qualified jobs in manufacturing activities and the incipient development of non-manual jobs (Balán, Browning, and Jelin 1973). Social class and migratory origins were important determinants of occupational attainment, but the relative abundance of skilled manual and unskilled non-manual positions facilitated upward mobility, even among individuals with lower class origins and rural migrants. The recession of the 1980s may have produced disruptions in individuals' careers and a temporary interruption of upward mobility. Nevertheless, the structural transformation of the economy outlined above also produced a further upgrading of Monterrey's occupational structure based on the expansion of nonmanual positions. In 1965, $24.5 \%$ of men where occupied in non-manual activities and $41.1 \%$ in unskilled manual jobs; by 2000 , these proportions had inverted, to $44.6 \%$ and $23.4 \%$ respectively ${ }^{2}$. On the other hand, non-manual positions suffered the greatest drop in real wages, thus reducing the wage gap between manual and non-manual jobs and probably some of the economic advantages of upward mobility (Solís 2002).

The restructuring of Monterrey's labor market in the last two decades is reminiscent of the transformations that characterize post-industrial societies (Bell 1973). Nevertheless, this convergence in economic and labor market trends with other cities in

\footnotetext{
${ }^{2}$ These figures correspond to male workers between ages 20 and 60. They were obtained from Jelin (1968) and data from the Monterrey sample of the National Survey of Urban Employment (ENEU).
} 
developed nations must be critically examined in light of the persistence of institutional and organizational characteristics inherent to developing societies. One of these characteristics, the high segmentation of labor markets into the formal and informal sectors of the economy, may have particularly important consequences for the study of job mobility. The sociological and economic literature on the informal sector in Latin America is vast, and there is still a wide debate about the characterization of informal activities. Those who emphasize structural limitations to economic growth visualize informal activities as a direct result of the lack of capacity of the "modern" sector for generating enough job opportunities (Tokman 1995). Self-employment or work in small, low-productivity firms is then conceived as a second-best occupational option. An alternative conceptualization emphasizes institutional regulation as the basic principle distinguishing formal from informal occupations, thus defining the informal sector as those activities that are "unregulated by the institutions of society, in a legal and social environment in which similar activities are regulated" (Castells \& Portes 1989: p.12). The common ground of these two perspectives is the implicit view of the informal sector as comprising jobs of inferior quality in terms of benefits, stability, and wages. However, the evidence regarding the inferiority of informal jobs is scarce and, in some cases, mixed (See for example: Marcouiller, Ruiz de Castilla, \& Woodruff 1997). In terms of occupational mobility, the segmentation of labor markets in formal and informal occupations may be linked to the existence of barriers to upward mobility, as well as to higher risks of unemployment and downward mobility for workers in informal jobs. Again there is virtually no empirical research on the subject. In this sense, the analysis of mobility patterns between workers in formal and informal jobs may contribute to elucidate whether the differences in job conditions between these two groups extend to unequal prospects of attainment across their occupational careers.

\section{Research Hypotheses}

The outlined characteristics of the socioeconomic development of Monterrey allow us to enumerate, in this section, the main hypotheses of this study. 
The effect of societal transformations. One of our main research questions is to what extent the transformations of the 1980s and 1990s affected men's process of entry into the labor force and subsequent occupational mobility. Yet, to explore this, it is important to distinguish between the short-term negative effects of the recession of the 1980s and the more permanent transformations in labor markets. Given the sustained transition from secondary to tertiary activities, we expect to observe continuity in the high rates of upward mobility that dominated up to the 1970s. However, our expectation is also to find negative period effects during periods of economic recession. These effects should be expressed in increasing rates of entry into the labor force in manual activities, as well as an increase in downward mobility.

The role of social origins. We are also interested in studying other characteristics of the occupational attainment process. In particular, we aim at exploring the effects of ascription and individual merit. A long-held debate in industrialized societies is whether ascribed characteristics - such as social class and other markers of social origins have gradually yield to educational attainment and to other indicators of individual merit as the principal determinants of individuals' position in society (Grusky 1994; Jonsson 1996; Marshall, Swift, and Roberts 1997; Treiman 1970). The extension of this debate to Latin American societies requires the consideration of both the persistent high levels of inequality and the absence of effective welfare policies to attenuate them. Despite overall improvements in standards of living (reflected in significant advances in indicators such as life expectancy, infant mortality, and educational levels), income inequality has persisted and even increased in recent years (Cortés 2001; ECLAC 2001; Londoño \& Székely 2000; Székely \& Hilgert 1999). The development of welfare programs aimed at alleviating these extreme inequalities has been very limited. In fact, social policies have been either plagued by corporativism and political-based preferences, which seriously limit their effectiveness, or circumscribed to the poorest population groups in rural areas, thus having a very limited impact in urban inequality levels ${ }^{3}$. In this context of high inequality and limited welfare programs aimed at "leveling the field" in the access to

\footnotetext{
${ }^{3}$ Currently, the most important public program to combat poverty in Mexico is "PROGRESA". However, so far its application has been limited to the poorest rural areas. A review of the characteristics of this program may be found in Gómez de León, Parker and Hernández (1999)
} 
opportunities, the family of origin and other informal social networks may represent an even more valuable resource for occupational attainment than in industrialized societies. We may then expect differences in the social position of the family of origin, as well as other indicators of social origins such as rural/urban background, to remain as important determinants of occupational attainment.

The impact of educational attainment. We also anticipate a strong effect of education on occupational outcomes, independently of men's social origins. The positive association between education and occupational attainment is consistence with status attainment theory, human capital theory and vacancy competition theory, although the explanations that each theory gives to this well established empirical facts are different (Blossfeld 1986). One of the most significant social transformations of the recent decades in Mexico is the increase in the schooling levels of the population. In the case of Monterrey, the proportion of males between ages 21 and 60 with less than primary education decreased from $50 \%$ in 1965 to $9 \%$ in 2000 , whereas the proportion with any college schooling increased from $6 \%$ to $26 \%$. With the increase in educational levels, attendance to secondary and higher education has expanded, thus affecting the timing and characteristics of the process of initial entry into the labor force. At the same time, the continuing upgrading of Monterrey's labor market, and particularly the expansion of service-class positions, may have implied an increasing demand for highly qualified individuals and consequently a valorization of academic qualifications in the labor market. Therefore, we expect educational attainment to be closely tied with men's initial allocation in the labor force as well as further occupational mobility patterns.

The Informal Sector and Job Mobility. As we pointed out in the previous section, one of the most remarkable characteristics of urban labor markets in Mexico is their segmentation in formal and informal occupations. We are interested in exploring how this segmentation is related to job mobility patterns, by investigating the differences in jobshift rates for men in formal and informal jobs. In our opinion, however, an appropriate empirical test must first take into account the structural heterogeneity of informal activities (Portes \& Sassen 1987). The most elemental distinction is between self- 
employed workers and employees or dependents (including family workers) who work under unprotected/unregulated labor conditions (hereafter "unprotected workers"). As we just described, self-employment in Latin America has often been described as a response coming "from below" to the inability of the formal sector to create enough job positions. However, there is more to self-employment than being merely a "refugee" activity. By definition, self-employed individuals create their own occupation. The self-employed generally have greater control over their jobs and a higher attachment to their occupations in relation to employees, and particularly to unprotected workers. Also, the relative autonomy of self-employment gives it a partial immunity against external economic conditions. Finally, self-employed individuals willing to change job and compete for a position in the labor market may be in a disadvantage in relation to other individuals who have a trajectory in formal positions, given their lack of experience and credentials in formal firms. We may then expect self-employed men to stay longer in their occupations than men in formal activities and unprotected workers. This should be reflected in lower job-shift rates, independently of the direction of the shift. In contrast, unprotected workers lack control over their occupations. They are highly vulnerable to lay-offs, because employers must not overcome any legal obstacle to dismiss them. In most cases, their chances of internal promotions are also limited, because internal labor markets are virtually not existent within small firms, and their prospects of downward mobility are higher, because once they become unemployed they may be more likely to accept lower level positions as "refugee" activities. We then anticipate downward mobility and mobility out of employment to be higher among unprotected workers than among formal laborers and self-employed men.

\section{Data, Models, And Variables}

Data. Our data are from the "Monterrey Occupational Mobility and Life Course Survey" $(\text { EMOC-MTY) })^{4}$ This survey was administered to 1,200 Monterrey men during the second semester of 2000. Respondents were equally distributed across three birth cohorts:

\footnotetext{
4 "Encuesta Sobre Movilidad Ocupacional y Curso de Vida en Monterrey 2000". A full description of the survey questionnaire, the sample design, and other technical aspects of the 2000 survey is provided by Solís (2002). Both the data set and the technical documentation of the survey are available from the first author upon request.
} 
1940-1949, 1950-1959, and 1960-1969. The main objective of the survey was to study current patterns of occupational mobility and compare them to those observed during the "substitution of imports" period of Mexican economy, which expanded from the 1940s to the beginning of the 1980s. To accomplish this task, the study took advantage of a pioneering survey on occupational mobility carried out in Monterrey in 1965 (see Balán, Browning and Jelin (1973)), which served as a baseline to trace historical changes in occupational mobility. ${ }^{5}$ Respondents to the EMOC-MTY survey were asked to reconstruct their complete occupational, residential, and family histories, as well as relevant aspects of their educational trajectories. Additional information on men's class background, current earnings, standards of living, and patterns of cultural consumption, was also collected in the survey. Occupational histories included the dates (year and month) of the beginning and ending for each occupation, the name of the occupation, the main activities performed in it, sector, type of contract, and health coverage benefits.

Our analysis is based on a hierarchical distinction between manual and nonmanual occupations. The focus on mobility between manual and non-manual positions intends to capture only the most relevant transitions in men's occupational lives, i.e. those job shifts that prompt significant changes in income levels and standards of living, as well as in life-worlds and life-styles. As we mentioned above, the wage gap between manual and non-manual positions has narrowed in recent decades, due to the drop of wages in the latter group. However, the wage differential between these two large groups of occupations is still significant. Besides, there are more than economic advantages associated to mobility from manual to non-manual positions. As in many other contexts, non-manual jobs in urban Mexico usually have higher status, entail more job benefits, and bring access to life-worlds and cultural goods not available to individuals in manual positions.

Models. Our analytical strategy (see Figure 1) is divided in two parts. First, we explore the determinants of men's initial allocation into the labor force. In many cases, lifetime differences in attainment levels manifest themselves from the very start of occupational

\footnotetext{
${ }^{5}$ However, in this paper we limit our analysis to the EMOC-MTY 2000 survey. Unfortunately, the complete life-history data for the 1965 survey are no longer available. The exclusion of women from this survey also implies that only men are considered in the analysis.
} 
careers. We explore these differences by using a multiple destination model to study the determinants of men's entry into the labor force into manual or non-manual positions. Since our interest is to analyze labor-force entry conditions in Monterrey, we exclude from this initial part of the analysis all those migrants who worked before arriving to the city (322 cases). The departing point for our analysis is age 12, and therefore we also exclude individuals who migrated to Monterrey after this age (89 cases), as well as those individuals who entered into the labor force before age 12 (35 cases). Thus, after eliminating cases with missing data we obtain a sub-sample of 733 cases, representing men who lived in Monterrey at age 12 and had not entered into the labor force by that age. We apply transition-rate models, and in particular piece-wise exponential models (Blossfeld and Rowher 2002) to this sub-sample, using the time to first entry into the labor force (in a monthly scale) as our dependent variable. It is worth mentioning that all men included in this sub-sample have had at least one job, and therefore all observations finish with an event.

\section{\{ FIGURE 1 ABOUT HERE \}}

In a second step, we analyze job mobility for men who already entered into the labor force. Here we focus on the outcome of job shifts, so we change from individuals to job spells as units of analysis. All job spells initiated in Monterrey are considered in the analysis, so many of the migrants who were excluded in the labor-force entry model are eventually included in the job-shift model. We estimate two different models according to starting status: one for job shifts from manual positions and the other for shifts from non-manual positions. We use again multiple-destination transition-rate models to identify the effects of different factors on job-shift outcomes. We focus on three different outcomes: job shifts to manual positions, job shifts to non-manual positions, and exits from the labor force. Job shifts to manual and non-manual positions can be alternatively interpreted as referring to upward, downward, or horizontal mobility, depending on the occupation of origin. An exit from the labor force is defined as any job spell that is not followed by another job within three months after its termination. In this latter case, the length of the episode is defined as the number of months from the beginning to the end of 
the job spell. In the case of job shifts to manual and non-manual positions, the length of the episode is defined as the number of months until the start of the new job. Finally, our analysis of job mobility is limited to the first six job spells in individuals' occupational trajectories. The characteristics and determinants of the mobility of highly mobile men may diverge from those of the majority of the population; by excluding job spells of high order we control this possible source of heterogeneity while losing only a limited number of cases (11\% of the total number of job spells).

Variables. Table 2 presents the explanatory variables used in the two sets of models. Some of these variables, such as father's occupation and educational attainment, are used both in the labor-force entry and job-shift models, but others are only used in one of the models. Some variables are fixed during the spells, while others are time-dependent. The estimation of models with time-dependent covariates is performed using episode splitting (Blossfeld and Rowher 2002). The description presented in Table 1 summarizes the characteristics of the variables.

"Father's occupation at birth" and "Migration status" are both indicators of men's social origins. In the case of father's occupation, the connection is with men's social class of origin, whereas in the case of migration status the interest is on the differences between Monterrey natives, migrants from rural areas, and migrants from other cities. These two variables will serve as our main indicators of the effects of ascribed characteristics on men's initial job allocation and further job mobility.

\{Table 2 about here

Educational attainment is included as a time-varying covariate. Educational histories are reconstructed using the information available on the highest educational level attained and on the age of exit from school. The main track in the Mexican educational system is organized in four levels: primary (6 years), secondary (3 years), preparatory ( 2 or 3 years), and professional ( 4 or 5 years). There are alternatives to this schooling path, such as studying a technical career along with secondary or preparatory studies, or following a career as primary school professor after secondary education. 
However, most men do follow the main track and for those who do not we transform their educational attainment into an equivalent scale. Also, only a handful of men never attended school, so we decided to group them along with those with less than primary education completed. There are five educational levels: "Less than primary", for those who did not complete the sixth grade of primary school; "Primary completed", "Secondary completed", and "Preparatory completed", grouping men who completed each successive level but had not completed yet the next level; and "First year of college", including all men who at least completed their first year of a professional career. We introduced a category for men with only one year of a professional career instead of completed college education, because some of the advantages associated to higher education may also be extended to men with incomplete college studies. Finally, independently of the level of education, the mere participation of men in the educational system may operate as a deterrent for the entry into the labor force ${ }^{6}$. We consider this effect by introducing in the labor-force entry model a dichotomous time-dependent variable ("Attendance to school"), which indicates whether or not a man is attending the educational system in a specific unit of time.

In order to assess empirically changes over time in the process of occupational attainment, we must first solve the problem of how to distinguish between the short-term negative effects of the crisis years in the 1980s and mid 1990s and the more permanent consequences of structural changes since the beginning of the 1980s. To do this, we rely on external measures of the short-term performance of Mexican economy and use these measures to obtain more substantive estimates of the impact of short-term economic conditions on mobility patterns ${ }^{7}$. We use two indicators: the annual growth rate of the Gross Domestic Product (GDP), and the annual inflation rate ${ }^{8}$. The GDP growth and

\footnotetext{
${ }^{6}$ The idea of considering the independent effect of educational level and participation in the school system was taken from the study of Blossfeld and Huinink (1991) on family formation.

7 There are two advantages associated to this analytical strategy (Blossfeld 1986; Blossfeld and Rowher 2002). First, by using external data on the economic conditions we avoid the identification problem that arises from the simultaneous inclusion in a statistical model of cohort and period effects based on chronological data. Second, period effects based on explicit measures of economic conditions are easier to interpret in theoretically relevant ways. In this case, period effects can be directly associated to short-term economic performance of the Mexican economy.

${ }^{8}$ The lack of available data for the complete period of analysis prevented us from using additional economic indicators. The GDP figures were obtained from the University of Groningen and The Conference Board, GGDC Total Economy Database, 2002, (http://www.eco.rug.nl/ggdc). The annual inflation rates were obtained from official figures provided by El Banco de México.
} 
inflation series from 1950 to 2000 are summarized in a unique index using principal components factor analysis. This index explains $76 \%$ of the variance in the two time series, and it is plotted in Figure 2. The index of short-term economic conditions reflects the positive performance of Mexican economy up to the beginning of the 1970s, followed by a mild recession in the first half of the 1970s and then the collapse of the 1980s. At the end of the 1980s there is a recovery of stability and economic growth, although at lower levels with respect to those observed up until the 1970s. Finally, the index also reflects the negative effects of the financial crisis of 1994-1995. The index of short-term economic conditions is included in both the labor-force entry and job-shift models as a time-dependent covariate ${ }^{9}$.

\{Figure 2 about here

In both models we include a second variable seeking to detect whether or not occupational attainment and mobility rates have changed during the 1980s and 1990s, independently of short-term variations in the performance of the Mexican economy. In the labor-force entry model we include birth cohort as a general measure of the period of entry into the labor force. Virtually all men pertaining to the youngest birth cohort (19651969) entered to the labor market after 1983, the year that marked the turn of the Mexican economy to the current model of economic growth. In the job-shifts models, we include a time-varying dichotomous variable ("Period") indicating whether men's exposure to a job shift takes place before 1983 or after this year. Although it would be incorrect to attribute the effects of these variables entirely to liberalization and economic restructuring during the $1980 \mathrm{~s}$ and $1990 \mathrm{~s}$, they may provide at least some preliminary evidence and point to future topics of research.

We also include two variables that reflect the effects of family events on men's occupational lives. In the labor-force entry model the emphasis is on events taking place in the family of origin, because generally the entry into the labor force precedes men's

\footnotetext{
${ }^{9}$ Like with other time-varying covariates, we used the method of episode splitting, in this case dividing the sample of individuals (labor-force entry model) or job spells (job-shift model) in sub-episodes every calendar year, and then updating the value of the index to the corresponding economic conditions of each year.
} 
transition from a family of origin to a family of procreation ${ }^{10}$. We have limited information on changes over time in the characteristics of the family of origin, and therefore we include only one time-varying variable indicating whether the respondent's father was still alive or had died. On the other hand, in the job-spells model our interest is in the effects of the transition from the family of origin to the family of procreation. To explore these effects we include a time-varying variable reflecting men's marital status.

In the job-shifts model we include three additional variables relating to the characteristics of men's initial position in the labor force. First, we use a variable measuring men's general labor-force experience, which indicates the number of months (in a year scale) that each individual has been employed since the start of his occupational career until the beginning of the current job spell. Second, the number of previous jobs intends to control for the unobserved heterogeneity introduced by having more than one job spell for some individuals (Allison 1984; Trappe \& Rosenfeld 1998). Finally, by introducing the "type of job" as an explanatory variable we account for the effects of men's position in Monterrey segmented labor markets. As we have discussed above, the "informal" sector comprises a set of heterogeneous activities and therefore it is important to distinguish between different kinds of occupations within this segment of the labor market. For this reason, instead of trying a dichotomous classification of "formal" and "informal" positions, here we define three groups of occupations. The first group consists of all positions that could be conceived as integrating the "formal" sector of the economy: employers, employees with written contract, and independent professionals. All the self-employed, including owners of small businesses with up to one employee but excluding independent professionals, integrate the second group. Finally, the third group represents the "unprotected workers", defined as employees and family workers with no written labor contract.

\footnotetext{
${ }^{10}$ Actually, only a handful of the men included in the labor force entry model married before entering into the labor force. This is not surprising if we conceive the transition to adulthood in the family sphere as being dependent on financial autonomy and, therefore, on men's active employment and further capacity to generate their own earnings.
} 


\section{Patterns of Labor-Force Entry}

Table 3 contains some descriptive statistics concerning the 733 men included in the labor-force entry model. The distribution by age of entry into the labor force indicates that this transition takes place relatively early in men's lives. A third of the men in the sample (32.6\%) entered before age 16, and another 38.6\% did it between 16 and 18 years of age. Only $7.2 \%$ of men experienced the death of their father before entering into the labor force, and four of every five (81.7\%) were Monterrey natives. The distribution by father's occupation reveals the predominance of working class origins, with $38.5 \%$ of men with lower manual background, versus only $24.2 \%$ and $9.8 \%$ with fathers in lower non-manual and higher non-manual activities, respectively. The distribution by educational level at the time of labor-force entry shows a polarization between lower and higher educational levels: the fraction of men who entered to work when they had only primary schooling or less represents $40 \%$ of the total, whereas those who entered into the labor force after completing a first year of college education account for $23.2 \%$ of the sample.

\{Tables 3 and 4 about here $\}$

In Table 4 we present the unadjusted effects of the independent variables on the labor-force entry rates to manual and non-manual occupations. These coefficients were obtained by fitting a single two-destination piecewise-exponential model for each independent variable, thus explicitly controlling for age only. A first look at the table shows that most of the variables that affect labor-force entry do so through their effect on the rate of entry into manual positions. This is the case with father's death, father's occupation, and educational level. It is important to be cautious when interpreting the absence of significant effects for the entry into non-manual positions. Certainly, such absence indicates that men with different class and educational backgrounds have similar rates of entry into non-manual positions. However, in order to obtain a complete picture of the differences by class of origin or education we must consider simultaneously the variations in entry rates into non-manual and manual positions. We illustrate this later in 
the paper, when we analyze the effects of men's class of origin in the multivariate model. For the moment, it is enough to call attention to the strong effect of the class of origin on the entry into manual positions. The rate of entry into manual positions is 3.8 times higher $(=\exp (1.338))$ for children of workers in lower non-manual positions, and 9.9 times higher $(=\exp (2.297))$ for children of lower manual workers, in relation to the children of men in higher non-manual positions. Only the differences by educational attainment - and particularly the contrast between men with college education and men with less than primary education — are of similar magnitude.

The only two variables with significant effects in both transitions to manual and non-manual positions are migration status and school attendance. The transition rates are significantly higher for migrants from urban areas in relation to natives, irrespectively of the position of entry. This suggests that urban migrants enter earlier into the labor force vis à vis natives, although not necessarily in a lower position. In contrast, for migrants from rural areas the only significant increase is in the rate of entry into manual positions, indicating a higher propensity of entry into lower-level occupations. On the other hand, the positive coefficients for men who leave the school system point to the high correlation between these two transitions.

Remarkably, the unadjusted models do not produce significant effects neither for birth cohort nor for the index of short-term economic conditions. The direction of the short-term economic conditions' coefficients is consistent with our expectations (the rate of entry into non-manual jobs increases and the rate of entry into manual positions decreases as short-term economic conditions improve). However, both coefficients do not reach statistically significant levels.

Results of the multivariate piecewise exponential model including simultaneously all explanatory variables are presented in Table 5. The baseline of the model controls for five age groups (the log of the baseline rates for these groups is included in the tables). There are few changes in the effects of most of the variables in relation to the unadjusted results presented in table 4 . Perhaps the most noticeable modification is that in the multivariate model we find a significant and consistent effect of short-term economic conditions and birth cohort on transition rates. The results suggest that in periods of economic recession and instability, the rate of entry into manual positions significantly 
increases, while the rate of entry into non-manual positions is not significantly altered. In other words, the coefficient of -0.111 associated to short-term economic conditions indicates that during periods of crisis - and particularly during the extreme recession of the 1980 s - there was an increase in the rate of entry of men into lower-level positions. On the other hand, after controlling for the negative effects of short-term economic conditions, we find a decrease in the rate of entry into manual positions for men in the youngest birth cohort (the coefficient is -0.324 ), which is consistent with the overall upgrading trends of Monterrey labor markets during the 1980s and 1990s. In sum, these results suggest that two overlapping structural forces have affected the initial allocation of Monterrey men into the labor force in the last two decades. First, the recession of the 1980s temporarily pushed men into low-level positions. Second, the more permanent upgrading of labor markets from manual to non-manual activities implied a reduction in transition rates to manual positions for the youngest cohort.

\{Table 5 about here

The multivariate model also confirms the strong effects of class origins. Despite the inclusion of educational attainment, migration status, and the participation in the school system, variables that typically absorb part of the influence of class of origin, father's occupation is still significantly associated to the rate of entry into manual positions. The adjusted rate of entry into manual positions is 4.7 times higher $(=\exp (1.554))$ for children of lower manual workers than for children of higher nonmanual workers ${ }^{11}$. A more detailed view of these differences is obtained in Figure 3, which depicts the simulated proportion of men who have entered into the labor force in manual and non-manual positions, according to father's occupation ${ }^{12}$. These proportions show that the vast majority of men with lower manual origins enter in the labor force in manual positions and before age 21. Men with higher non-manual origins, in contrast,

\footnotetext{
${ }^{11}$ To explore in greater detail the differences in entry rates by class of origin, we fitted additional models including the interaction between age of entry and father's occupation. None of these models produced statistically significant differences, and therefore we decided to exclude them from this article.

${ }^{12}$ The graph only shows the simulated proportions for men with higher non-manual and lower manual origins. To obtain these proportions we constructed a multiple-decrement life table using the rates
} 
enter relatively late into the labor force. Their position of entry is equally distributed between manual and non-manual jobs up to age 21, but after that age - which coincides with the exit from college for those who completed a professional career - most of the men who remain out of the labor force enter into non-manual positions.

Finally, the model also shows consistent effects for educational attainment. The rate of entry into non-manual positions is $1.72(=\exp (0.545))$ times higher for men with secondary education completed, 2.41 times $(=\exp (0.879))$ higher for men with preparatory completed, and 2.53 times $(=\exp (0.927))$ higher for men with any college education, in relation to men with less than primary schooling. Moreover, the rate of entry into manual positions is 4.7 times lower $(=\exp (1.540))$ for men with university education than for men with less than primary, suggesting that attaining any college education practically guarantees the access of men to non-manual positions. It is worth noticing that the effects of educational attainment are independent of whether or not men are still participating in the school system, because the attendance to school variable is also included in the model. In relation to this variable and as might be expected, dropping from school significantly increases the rate of entry into the labor force. The estimated entry rates increase 2.99 times $(=\exp (1.095))$ for manual positions and 2.15 times $(=\exp (0.767))$ for non-manual occupations.

\section{Job-Shift Patterns}

We now turn our attention to job mobility within men's occupational trajectories, by analyzing job-shift rates from manual and non-manual positions. Note that in this case our unit of analysis changes from individuals to job spells. Each job spell represents an episode, which is further divided into sub-episodes to account for value changes in timevarying covariates. In Table 6 we present some characteristics of the job spells, including their distribution according to the independent variables. The average number of job spells per individual is $3.66^{13}$. Only $15.1 \%$ of the job shifts from manual positions end in upward mobility; $13.0 \%$ end in a prolonged exit from the labor force, and $52.4 \%$ can be

estimated with the model in Table 5. The value of the other independent variables was set to the average shown in Table 2. 
defined as horizontal moves. In the case of job shifts from non-manual positions, downward mobility represents $9.3 \%$, exits from the labor force $9.9 \%$, and horizontal mobility $55.8 \%$ of the moves. The higher proportion of job shifts that are either rightcensored or end in horizontal moves already suggests a higher degree of class stability for men in non-manual jobs.

Descriptive statistics also show the unequal distribution of manual and nonmanual job spells among men with different class background and educational attainment levels. Only $13.9 \%$ of manual job spells belong to men with fathers in either lower or higher non-manual positions, versus $43.3 \%$ of non-manual job spells. Similarly, $4.9 \%$ of manual job spells pertain to men with college education, versus $53.2 \%$ of non-manual job spells. These differences, along with the results of the labor-force entry model, serve to remind us that the state of origin in the models presented later is not independent of social class and educational attainment. As a consequence, some of the effects of ascription and attainment are weakened by this initial selectivity of men into their positions of origin.

\section{\{Tables 6 and 7 about here}

The results of the unadjusted multiple-destination models for job transitions are presented in Table 7. Note again that these estimates are obtained from two different models, one for manual positions of origin and the other for non-manual positions. The two variables reflecting men's overall labor-force experience - years of labor-force experience and number of previous jobs - produce negative coefficients for most transitions, suggesting a general trend towards the reduction of mobility as individuals move forward in their occupational trajectories. This particular form of time-dependence in job-shift rates has been attributed to the reduction in the discrepancy between resources and current job rewards or, in other words, between current and potential jobs, as individuals move forward in their occupational careers (Sørensen 1977). However, it is difficult to discern whether the effects of labor-force experience and number of previous jobs are actually due to the reduction of the mismatch between individual skills and

\footnotetext{
${ }^{13}$ It is important to remember that only job spells that started in Monterrey are included, due to our interest in analyzing job-shift patterns within the city. If we also consider the job spells of migrants before their arrival in Monterrey, the average number of job spells per individual increases to 4.5.
} 
positions, or to their high correlation with age ${ }^{14}$. An alternative hypothesis would be that, independently of their qualifications and levels of attainment, men tend to reduce their willingness to change jobs as they advance from the initial to later stages of their occupational life courses. This might in part be due to age-related social norms prescribing the "appropriate" timing for job searching and career settlement across individual lives (Settersten \& Hagestad 1996).

The type of job is also correlated to job-shift rates. In general, the results are consistent with our initial hypotheses: mobility from self-employment tends to be lower than from formal or unprotected jobs. In the case of self-employed workers, upward mobility is 5.40 times $(=\exp (1.687))$ less frequent than for workers in the formal sector, whereas horizontal mobility is 2.14 times $(=\exp (0.761))$ less likely in manual activities and 7.67 times $(=\exp (2.037))$ in non-manual positions. In contrast with self-employed workers, unprotected workers experience higher mobility rates to manual jobs and out of employment. The effect is stronger for men in non-manual positions, with downward mobility 1.97 times $(=\exp (0.678))$ higher and out of employment rates 3.34 times $(=\exp (1.206))$ higher for unprotected employees than for men in formal activities.

The index of short-term economic conditions has only significant effects on the transition from manual to non-manual positions. The positive coefficient for this transition is in harmony with the interpretation of upward mobility rates as an outcome of economic expansion: in periods of high economic growth and price stability there is an increase in the demand of non-manual positions, and as a result upward mobility rates also increase. In contrast, it is difficult to find a consistent pattern for period effects, because both upward and downward mobility rates seem to decrease in the period 19832000 in relation to previous years.

Men's change of marital status has also a negative association with job transition rates, although this effect is only significant for job spells from manual positions. Transition rates from manual positions are reduced in a half $(=\exp (-0.673))$, a third $(=\exp (-0.393))$ and two thirds $(=\exp (-1.084))$ in the cases of non-manual, manual, and out of employment destinations, respectively.

\footnotetext{
${ }^{14}$ In our sample, age at the start of the job has a correlation of 0.88 and 0.59 with labor force experience and number of previous jobs, respectively.
} 
The two variables directly linked to men's social origins are also significantly associated to transition rates. Rural migrants show lower upward mobility rates and higher downward mobility rates than natives. A similar pattern may be found in relation to men's class of origin: men with manual origins are significantly less likely to experience upward mobility and more likely to experience downward mobility than men with non-manual positions. In the case of downward mobility, for instance, the unadjusted downward mobility rate is more than sixteen times higher for men with higher and lower manual origins than for men with higher non-manual origins.

There is a strong association between educational attainment and job mobility patterns. Men are significantly more likely to experience upward mobility and less likely to experience downward moves as their educational levels increase from less than primary to college. The unadjusted results also suggest an increase in rates out of employment for men in manual positions. However, it is difficult to interpret these coefficients, because they may be either associated to higher job stability or to a temporary withdrawal from the labor force to return to full-time education.

Table 8 presents the results of the multivariate competing risks models. It can be noted that, controlling for other variables, the number of years of labor-force experience maintains its negative effect on job transition rates, although some of the coefficients lose significance. The number of previous jobs has inconsistent effects depending on the origin and destination of the movement, but the only significant coefficient (0.173) is associated to lateral moves within manual positions ${ }^{15}$.

\{Table 8 about here

In general, the effects of the type of job are retained in the multivariate model. Transition rates are lower for the self-employed in relation to men in formal labor conditions. On the other hand, the rate of exit from employment increases for men in unprotected labor conditions. These results support the idea that in order to evaluate the mobility prospects

\footnotetext{
15 There may be a collinearity problem between the years of labor force experience and the number of previous jobs, which might affect the coefficients for both variables. The correlation between these two variables is 0.66 . We tested additional models alternatively including only one of the two variables and the results are more consistent with those presented in Table 7.
} 
of individuals in the informal sector it is important to establish at least an elementary distinction between the self-employed and unprotected laborers. Of course, the models do not inform us about the determinants of the transition to self-employment, but they certainly indicate that once they become self-employed, men are significantly less likely to experience job mobility, even after considering other factors such as labor-force experience, economic conditions, class of origin, and educational level. On the other hand, if our interest is on job vulnerability, then our attention must be focused on workers in unprotected labor conditions.

In relation to short-term economic conditions, the coefficients point in the expected direction: economic expansion is associated to higher rates of upward mobility and lower rates of downward mobility. However, only the coefficient for horizontal job shifts within manual positions reaches significance levels. The historical period in which the job shift takes place does not have either a significant effect on job transition rates. There are several possible explanations for these results. One of them is that our measure of overall economic conditions based on national GDP growth and inflation rates fails to capture in enough detail the economic situation of Monterrey, thus weakening the significance levels of the coefficients. An alternative interpretation is that the impact of both short-term economic conditions and more perdurable changes in the model of economic growth manifests primarily in the entry into the labor force, and therefore we must look for these effects in the labor-force entry model presented in the previous section. In any case, the evidence produced by the job-shift models indicates that, once short-term economic conditions are considered, mobility rates do not significantly vary after 1983, thus suggesting a negligible effect of liberalization and economic restructuring.

In the multivariate model, both marital and migration status lost their significance as factors affecting job transition rates. Perhaps this is due to their correlation with laborforce experience and father's occupation, respectively, which were not considered in the unadjusted models. Married men tend to be older and have more work experience than single men, and fathers of migrants from rural areas are more often in lower manual occupations than fathers of migrants from urban areas and natives. It should not be surprising then that, once these two variables are included in the model, the significance 
of marital and migration status is reduced. In sum, neither the transition from a family of origin to an own family, nor the rural-urban origin of men, have a significant effect on job transition rates in Monterrey, once confounding variables are controlled for ${ }^{16}$.

Men's class of origin, expressed in their fathers' occupation at birth, also retained its significant effects on upward and downward mobility rates, although in the latter case the magnitude of the coefficients is notably reduced after controlling for other variables. Upward mobility rates are 2.8 times $(=\exp (1.025))$ and 4.1 times $(=\exp (1.563))$ higher for men with higher non-manual origins than for men with lower non-manual origins and lower manual origins, respectively. The rate of downward mobility is more than five times higher $(=\exp (1.706))$ for children of lower manual workers. Thus, in accordance to our initial hypothesis, men's class of origin remains an important determinant of occupational attainment in Monterrey, with effects not only on men's initial allocation in the labor force, but also on the prospects of job mobility within their occupational careers.

Finally, job-shift patterns remain closely related to men's educational attainment. There is a gradual increase in upward mobility rates with education. The estimated gap in rates between extreme groups (first year of college versus less than primary) exceeds the ratio of six to one $(=\exp (1.922))$. In relation to downward mobility, the effects of educational attainment are even more dramatic: downward moves are more than ten times less likely $(=\exp (-2.466))$ for men with preparatory education and almost twenty times less likely (=exp(-2.978)) for men with any college schooling, in relation to men with less than primary education. Thus, as expected according to a variety of theoretical frameworks, higher credentials seem to enhance men chances of move upward in the occupational hierarchy, and also exert a strong protective effect against downward mobility, even controlling for other factors such as job experience and social class of origin.

\section{Summary and Discussion}

\footnotetext{
${ }^{16}$ The exception is the transition to out of employment for manual workers, that reduces by half (=exp($0.721)$ ) among married men. This may be related to the greater pressure that married men have as "bread winners" to remain employed in comparison to single men, who can afford more time out of the labor force to search for better positions or return to full-time education.
} 
Our analyses reveal two of the most salient characteristics of recent patterns of occupational mobility in Monterrey. First, after the short-term negative effects of the debt-crisis of the 1980s - mainly expressed through a temporary increase in the rate of entry into the labor force in low-level occupations - the dominant trend of upward mobility that characterized the "substitution of imports" period resumed, due in great part to the massive transfer of workers from manufacturing to services. Second, the two most relevant components of the process of occupational attainment, namely the initial allocation of men into the labor force and further patterns of vertical mobility within individuals' careers, remain significantly affected by ascribed characteristics, and particularly by men's class of origin.

At first glance, then, there seems to be more continuity than change in the process of occupational mobility in relation to the years of sustained economic growth that characterized the substitution of imports period, before the decade of the 1980s. In their analysis of mobility patterns in the 1960s, Balán, Browning and Jelin (1973) emphasized the continuing upgrading of Monterrey's occupational structure, which facilitated upward mobility, despite the persistence of inequality in attainment levels. Our results suggest that, once the temporary negative effect of the crisis of the 1980s passed, this process continued with little change, this time fueled by the expansion of non-manual activities. However, this apparent continuity must be critically examined in light of the substantial losses in real wages during the debt-crisis of the 1980s and the financial crisis of the mid1990s. We have devoted little attention to wages, because the information available is limited to men's current jobs and therefore it is not possible to analyze income mobility. However, the indirect evidence that can be obtained from comparing men's incomes in 1965 and 2000 suggests that non-manual workers, and especially workers in lower-level white-collar positions, have suffered the largest losses in average incomes. The latter occupational group is precisely the one with the highest expansion rate in the two last decades, and the most common destination for men experiencing upward mobility. Thus, the continuity in upward mobility rates during the last two decades seems to have come with a hard price: the reduction of the economic returns associated to upward moves.

The other remarkable feature is the continuing importance of men's class of origin in occupational attainment. The occupation of the father remains a strong predictor of 
men's position of entry into the labor force. Furthermore, patterns of mobility are also affected by social origins, even after the initial entry into the labor force, in a mechanism that could be described as a "continuing adjustment" of origins to destination. We have linked the persistent importance of social origins to the virtual absence of welfare policies aimed at attenuating social and economic inequalities and their effects on class reproduction. In the last two decades, perhaps the only significant public policy effort to "level the field" and reduce class disadvantages in the labor market has been the continuing expansion of public schooling, and particularly of secondary and university education. However, large inequalities in the access to higher education persist (Solís 2002). In addition, the expansion of higher education has given origin to new forms of inequality, such as the distinction between private education, accessible only to children of wealthy families, and the lower-quality public education, which is much less expensive, but has gradually reduced academic standards as enrolling in public universities has increased at higher rates than their budgets. Thus, it is not surprising to find that men's class of origin remains a strong predictor of their occupational trajectories, even after controlling for educational attainment.

The results of the paper also point to the importance of considering membership to the informal economy as a predictor of occupational attainment. We emphasized the need to distinguish between two different groups that have often been classified together as part of the "informal sector": the self-employed and unprotected workers. When compared to men in formal activities, the self-employed tend to have lower job mobility rates, suggesting that they either face higher barriers against mobility or prefer to keep working as self-employed than exploring other activities. On the other hand, unprotected employees seem to be more vulnerable than formal workers and the self-employed, and this is reflected in their higher rates of exit from employment. The differences in mobility patterns between the self-employed and unprotected workers advise us on the difficulties of attempting a clear-cut characterization of informal activities. Our suggestion is that, in order to understand labor-market segmentation and its implications in work lives, it is necessary to transcend the black and white perspective of the informal/formal divide and to look at the different constellations of activities that are generally encompassed into the "informal economy" category. 
Finally, our analysis may also serve to illustrate some of the differences between occupational mobility regimes between Latin American cities and their counterparts in industrialized societies. Latin American cities have not been isolated from the intense economic transformations brought by the increasing integration of global markets in the last two decades. However, these structural transformations have taken place in a historical and institutional context significantly different from that of developed societies. These differences imprint a specific seal to the restructuring of labor markets and occupational mobility regimes. As we have seen in this article, in the case of Monterrey, the most remarkable trends have been a continuing expansion of tertiary activities, accompanied by very significant reductions in wages and the continuing importance of ascription as a determinant of occupational attainment. Our case study cannot be generalized as such to other Mexican and Latin American cities. Nevertheless, given that Monterrey is one of the few cases that could be characterized as a prosperous "global city" in Latin America (Cerutti 2000; Pozas 2002), we may expect a similar or even more negative outlook for other cities across the sub-continent. More empirical research is needed to determine how economic liberalization and globalization have altered occupational mobility regimes throughout the variety of national and regional experiences. This is certainly one of the most promising lines of inquiry for scholars interested on the effects of structural change on social stratification in Latin American societies. 


\section{References}

Allison Paul David. 1984. Event history analysis regression for longitudinal event data. Beverly Hills, Calif: Sage Publications.

Balán Jorge. 1968. The Process of Stratification in a Developing Society: The Case of Monterrey, Mexico. Thesis. University of Texas at Austin.

Balán Jorge, Browning Harley L, Jelin Elizabeth. 1973. Men in a developing society geographic and social mobility in Monterrey, Mexico. Austin: Published for the Institute of Latin American Studies by the University of Texas Press.

Bell Daniel. 1973. The coming of post-industrial society a venture in social forecasting. New York: Basic Books.

Blau Peter M., Duncan Otis D. 1967. The American Occupational Structure New York: John Wiley

Blossfeld Hans-Peter. 1986. Career Opportunities in the Federal Republic of Germany: a Dynamic Approach to the Study of Life-Course, Cohort, and Period Effects. European Sociological Review 2:208-25

Blossfeld Hans-Peter, Huinink Johannes. 1991. Human Capital Investments or Norms of Role Transition? How Women's Schooling and Career Affect the Process of Family Formation? American Journal of Sociology 97(1):143-68

Blossfeld Hans-Peter, Rohwer Götz. 2002. Techniques of Event History Modeling. Mahwah, NJ: Lawrence Erlbaum Associates.

Boltvinik Julio. 2001. Dinámica y Características de la Pobreza en México. In La Población de México: Tendencias y Perspectivas sociodemográficas hacia el Siglo XXI, ed. Gómez de León José, Rabell Cecilia, México, DF: Fondo de Cultura Económica.

Castells Manuel, Portes Alejandro. 1989. World underneath: the origins, dynamics, and effects of the informal economy. In The Informal economy studies in advanced and less developed countries, ed. Portes Alejandro, Castells Manuel, Benton Lauren A, Baltimore, Md: Johns Hopkins University Press.

Cerutti Mario. 1992. Burguesía, capitales e industria en el norte de México Monterrey y su ámbito regional (1850-1910). México: Alianza Editorial. Facultad de Filosofía y Letras de la Universidad Autónoma de Nuevo León. 
Cerutti Mario. 2000. Propietarios, empresarios y empresa en el norte de México Monterrey: de 1848 a la globalización. México, D.F: Siglo Veintiuno Editores.

Cortés Fernando. 2001. Distribución del Ingreso y Población en el México Contemporáneo. In La Población de México: Tendencias y Perspectivas sociodemográficas hacia el Siglo XXI, ed. Gómez de León José, Rabell Cecilia, México, DF: Fondo de Cultura Económica.

DiPrete Thomas A., De Graff Paul M., Luijkx Ruud, Tåhlin Michael, Blossfeld HansPeter. 1997. Collectivist versus Individualist Mobility Regimes? Structural Change and Job Mobility in Four Countries. American Journal of Sociology $103(2): 318-58$

ECLAC. 2001. 2001: Current Conditions and Outlook. Santiago, Chile: Economic Commission for Latin America and the Caribbean.

Erikson R., Goldthorpe J. H. 1992. The Constant Flux: A Study of Class Mobility In Industrial Societies. Oxford: Clarendon Press.

Esping-Andersen Gøsta. 1993. Changing classes stratification and mobility in postindustrial societies. London, Newbury Park, Calif: Sage Publications.

Featherman David L, Hauser Robert Mason. 1978. Opportunity and change. New York: Academic Press.

Germani Gino. 1959. Social Mobility in Argentina. In Social mobility in industrial society, ed. Lipset Seymour Martin, Bendix Reinhard, Berkeley: University of California Press.

Gómez de León José, Parker Susan, Hernández Daniel. 1999. PROGRESA: A New Strategy to Alleviate Poverty in Mexico. Social Policy Conference, World Bank. González de la Rocha Mercedes. 1994. The resources of poverty women and survival in a Mexican city. Oxford, UK, Cambridge, USA: Blackwell.

Grusky David B. 1994. Social stratification class, race, and gender in sociological perspective. Boulder, Colo: Westview Press.

Jelin Elizabeth. 1968. Men and jobs: lifetime occupational changes in Monterrey, Mexico. Thesis. University of Texas at Austin.

Jonsson Jan O. 1996. Stratification in Post-Industrial Society. In Can education be equalized? the Swedish case in comparative perspective, ed. Erikson Robert, 
Jonsson Jan O, Boulder, Colo: Westview Press.

Kerckhoff Alan C. 1995. Institutional Arrangements and Stratification Processes in Industrial Societies. Annual Review of Sociology 15:323-47

Londoño Juan Luis, Székely Miguel. 2000. Persistent Poverty and Excess Inequality: Latin America, 1970-1995. Journal of Applied Economics 3(1):93-134

Lustig Nora. 1998. Mexico the remaking of an economy. Washington, DC: Brookings Institution Press.

Marcouiller Douglas, Ruiz de Castilla Verónica, Woodruff Christopher. 1997. Formal Measures of the Informal-Sector Wage Gap in Mexico, El Salvador, and Peru". Economic Development and Cultural Change 45(2):367-92

Marshall Gordon, Swift Adam, Roberts Stephen. 1997. Against the odds? social class and social justice in industrial societies. Oxford, New York: Clarendon Press. Oxford University Press.

Martin Gary. 2000. Employment and unemployment in Mexico in the 1990s. Monthly Labor Review 123(11):3-18

Mayer Karl Ulrich. 2001. The paradox of global social change and national path dependencies. Life course patterns in advanced societies. In Inclusions and Exclusions in European Societies, ed. Woodward Alison, Kohli Martin, New York: Routledge.

Muñoz Humberto, Oliveira Orlandina de, Stern Claudio. 1977. Migración y desigualdad social en la ciudad de México. México: Instituto de Investigaciones Sociales, Universidad Nacional Autónoma de Mexico.

Portes Alejandro, Sassen Saskia. 1987. Making it underground: comparative materials on the informal sector in western markets economies. American Journal of Sociology 93(1):30-61

Pozas María de los Angeles. 2002. En Monterrey, luz y sombra de la globalización. Proceso. Semanario de Información y Análisis 1324

Pozos Ponce Fernando. 1996. Metrópolis en reestructuración. Guadalajara y Monterrey, 1980-1989. Guadalajara, Jalisco, Mxico: Universidad de Guadalajara.

Selby Henry A, Murphy Arthur D, Lorenzen Stephen A. 1990. The Mexican urban household organizing for self-defense. Austin: University of Texas Press. 
Settersten Richard, Hagestad Gunhild. 1996. What's the Latest? Cultural Age Deadlines for Education and Work Transitions. The Gerontologist 36(5):178-88

Solís Patricio. 2002. Job Mobility, Occupational Careers and Social Change in Monterrey, México. Thesis. Austin: University of Texas at Austin.

Sørensen Aage B. 1977. The Structure of Inequality and the Process of Attainment. American Sociological Review 42(6):965-78

Székely Miguel, Hilgert Marianne. 1999. The 1990s in Latin America: Another Decade of Persistent Inequality. Luxembourg Income Study Working Paper No. 235. Luxembourg.

Tokman Victor E. 1995. El sector informal en América Latina dos décadas de análisis. Mexico, D.F: Consejo Nacional para la Cultura y las Artes.

Trappe Heike, Rosenfeld Rachel A. 1998. Gender Inequality at Work in the Early Adult Lifecourse: A Comparison of Job-Shifting Patterns in the Former East Germany and the Former West Germany. European Sociological Review 14:343-68

Treiman Donald J. 1970. Industrialization and social stratification. In Social Stratification: Research and Theory for the 1970s, ed. Laumann Edward O., Indianapolis : Bobbs-Merrill.

Tuirán Rodolfo. 1993. Las respuestas de los hogares de sectores populares urbanos frente a la crisis: el caso de la Ciudad de México. In Población y desigualdad social en México, ed. Béjar Navarro Raúl, Hernández Bringas Héctor, Bar-Din Anne, Cuernavaca, Mor: Universidad Nacional Autónoma de México, Centro Regional de Investigaciones Multidisciplinarias.

World Bank, ADB, IADB, IMF, EBRD. 2001. A globalized market . Opportunities and risks for the poor. 
Tables And Figures

Table 1. Distribution of the Active Population by Type of Industry, Monterrey, 1966- 1998

\begin{tabular}{lrrrrrrrr}
\hline & $\mathbf{1 9 6 6}$ & $\mathbf{1 9 7 8}$ & $\mathbf{1 9 8 3}$ & $\mathbf{1 9 8 7}$ & $\mathbf{1 9 9 1}$ & $\mathbf{1 9 9 4}$ & $\mathbf{1 9 9 6}$ & $\mathbf{1 9 9 8}$ \\
\cline { 2 - 8 } Extractive* & 2.2 & 2.5 & 1.8 & 1.6 & 0.8 & 0.4 & 0.6 & 0.3 \\
Manufacturing & 40.9 & 36.5 & 31.1 & 27.3 & 28.1 & 24.5 & 25.8 & 27.8 \\
Construction** & 7.7 & 8.5 & 9.5 & 8.8 & 7.3 & 9.4 & 7.4 & 7.6 \\
Commerce & 17.3 & 16.1 & 16.0 & 18.8 & 21.6 & 22.5 & 22.2 & 22.5 \\
Transport & 6.8 & 4.7 & 5.0 & 4.6 & 5.2 & 5.4 & 5.4 & 5.7 \\
Services & 25.1 & 31.7 & 36.6 & 39.0 & 37.0 & 37.8 & 38.6 & 36.1 \\
Total & $\mathbf{1 0 0 . 0}$ & $\mathbf{1 0 0 . 0}$ & $\mathbf{1 0 0 . 0}$ & $\mathbf{1 0 0 . 0}$ & $\mathbf{1 0 0 . 0}$ & $\mathbf{1 0 0 . 0}$ & $\mathbf{1 0 0 . 0}$ & $\mathbf{1 0 0 . 0}$ \\
\hline
\end{tabular}

* Includes agriculture, mining and oil extraction

** Includes workers in utility services

Sources: 1966: Balán 1968, p. 49; 1978, 1983: Pozos 1992, p. 186; 1987-1998: National Survey of Urban Employment, $2^{\text {nd }}$ quarters 
Table 2. Description of the Variables included in the Models

Variable Type Groups

A. Variables included both in the Labor Force Entry and the Job-Shifts Model

$\begin{array}{lll}\text { Migration Status } & \text { time-fixed } & \text { 1. Monterrey Natives } \\ & & \text { 2. Migrants from Rural Area }(<5,000 \text { residents }) \\ & & \text { 3. Migrants from Urban Area }(>5,000 \text { residents }) \\ \text { Father's Occupation } & \text { time-fixed } & \text { 1. Higher Non-Manual } \\ & & \text { 2. Lower Non-Manual } \\ & & \text { 3. Higher Manual } \\ & & \text { 4. Lower Manual } \\ \text { Educational Level } & \text { 1. Less than Primary } \\ & \text { time- } & \text { 2. Primary Completed } \\ & \text { dependent } & \text { 3. Secondary Completed } \\ & & \text { 4. Preparatory Completed } \\ & & \text { 5. One year of College Completed } \\ \text { Short-Term Economic Conditions } & \text { (continuous }- \text { see Figure } 2 \text { and article text for } \\ & \text { time- } & \text { further details) }\end{array}$

B. Variables included only in the Labor force entry model

\begin{tabular}{|c|c|c|}
\hline School Attendance & $\begin{array}{l}\text { time- } \\
\text { dependent }\end{array}$ & $\begin{array}{l}\text { 0. Not attending schoo } \\
\text { 1. Attending school }\end{array}$ \\
\hline Birth Cohort & time-fixed & $\begin{array}{l}\text { 1. } 1940-1954 \\
\text { 2. } 1955-1964 \\
\text { 3. } 1965-1970\end{array}$ \\
\hline Father's Death & $\begin{array}{l}\text { time- } \\
\text { dependent }\end{array}$ & $\begin{array}{l}\text { 0. Father alive } \\
\text { 1. Father dead }\end{array}$ \\
\hline
\end{tabular}

C. Variables included only in the Job-shifts models

$\begin{array}{lll}\text { Period } & \text { time- } & 0 . \text { Before } 1983 \\ \text { dependent } & \text { 1. After } 1983 \\ \text { Marital Status } & \text { time- } & \text { 0. Single } \\ & \text { dependent } & \text { 1. Married } \\ \text { Labor Force Experience } & \text { time-fixed } & \text { (continuous } \text { - year scale) } \\ \text { Number of Previous Jobs } & \text { time-fixed } & \text { (continuous) } \\ \text { Type of Job } & \text { time-fixed } & \text { 1. Formal } \\ & & \text { 2. Self-employed } \\ & & \text { 3. Unprotected workers }\end{array}$


Table 3. Characteristics of Men Included in the Labor Force Entry Model

\begin{tabular}{|c|c|c|}
\hline & $\%$ & cases \\
\hline \multicolumn{3}{|l|}{ Age of Entry } \\
\hline $12-15$ & 32.6 & 239 \\
\hline $16-18$ & 38.6 & 283 \\
\hline $19-21$ & 16.6 & 122 \\
\hline $22-30$ & 12.1 & 89 \\
\hline \multicolumn{3}{|l|}{ Birth Cohort } \\
\hline $1940-1954$ & 42.3 & 310 \\
\hline $1955-1964$ & 36.8 & 270 \\
\hline $1965-1970$ & 20.9 & 153 \\
\hline \multicolumn{3}{|l|}{ Father's Death } \\
\hline Father Alive & 92.8 & 680 \\
\hline Father Dead & 7.2 & 53 \\
\hline \multicolumn{3}{|l|}{ Migration Status } \\
\hline Natives & 81.7 & 599 \\
\hline Rural Migrants & 9.0 & 66 \\
\hline Urban Migrants & 9.3 & 68 \\
\hline \multicolumn{3}{|l|}{ Father's Occupation } \\
\hline Higher Non-Manual & 9.8 & 72 \\
\hline Lower Non-Manual & 24.2 & 177 \\
\hline Higher Manual & 27.6 & 202 \\
\hline Lower Manual & 38.5 & 282 \\
\hline \multicolumn{3}{|l|}{ Educational Level } \\
\hline Less than Primary completed & 13.5 & 99 \\
\hline Primary completed & 26.5 & 194 \\
\hline Secondary completed & 27.8 & 204 \\
\hline Preparatory completed & 9.0 & 66 \\
\hline First year of College & 23.2 & 170 \\
\hline \multicolumn{3}{|l|}{ School attendance } \\
\hline Not attending school & 45.3 & 332 \\
\hline Attending school & 54.7 & 401 \\
\hline
\end{tabular}

Source: EMOC-MTY Survey 
Table 4. Estimates of Bivariate Two-destination Transition-rate Models for Labor Force Entry in Manual or Non-Manual Positions, Monterrey Men Born Beetween 1940 and 1970 (controlling for age)

\begin{tabular}{|c|c|c|c|c|}
\hline & \multicolumn{2}{|c|}{ Manual } & \multicolumn{2}{|c|}{ Non-Manual } \\
\hline & Coeff. & S.E. & Coeff. & S.E. \\
\hline \multicolumn{5}{|l|}{ Birth Cohort } \\
\hline $1940-1954$ & ------ & ------ & ------ & ------ \\
\hline $1955-1964$ & 0.067 & $(0.113)$ & -0.028 & $(0.124)$ \\
\hline $1965-1970$ & -0.024 & $(0.135)$ & -0.174 & $(0.146)$ \\
\hline \multicolumn{5}{|l|}{ Short-Term Economic Conditions } \\
\hline $\begin{array}{l}\text { Father's Death } \\
\text { (time-varying covariate) }\end{array}$ & $0.491 * *$ & $(0.193)$ & 0.052 & $(0.213)$ \\
\hline \multicolumn{5}{|l|}{ Migration Status } \\
\hline Migrants from Rural Community & $0.643 * * *$ & $(0.159)$ & 0.256 & $(0.232)$ \\
\hline Migrants from Urban Community & $0.438 * * *$ & $(0.168)$ & $0.421 * *$ & $(0.199)$ \\
\hline \multicolumn{5}{|l|}{ Father's Occupation } \\
\hline Lower Non-Manual & $1.338 * * *$ & $(0.356)$ & 0.058 & $(0.158)$ \\
\hline Higher Manual & $2.200 * * *$ & $(0.345)$ & 0.080 & $(0.174)$ \\
\hline Lower Manual & $2.297 * * *$ & $(0.342)$ & 0.053 & $(0.167)$ \\
\hline \multicolumn{5}{|l|}{ Educational Level (time-varying covariate) } \\
\hline Primary completed & 0.105 & $(0.152)$ & 0.478 & $(0.287)$ \\
\hline Secondary completed & $-0.640 * * *$ & $(0.187)$ & 0.237 & $(0.322)$ \\
\hline Preparatory completed & $-1.448 * * *$ & $(0.268)$ & 0.364 & $(0.359)$ \\
\hline First year of College & $-2.908 * * *$ & $(0.356)$ & 0.305 & $(0.328)$ \\
\hline $\begin{array}{l}\text { School Attendance } \\
\text { (time-varying covariate) }\end{array}$ & $1.537 * * *$ & $(0.103)$ & $0.561 * * *$ & $(0.119)$ \\
\hline
\end{tabular}

$* \mathrm{p}<0.1, * * \mathrm{p}<0.05, * * * \mathrm{p}<.01$

Source: EMOC-MTY Survey 
Table 5. A Multiple-destination Multivariate Transition-rate Model to the First Job (Non-Manual vs. Manual Positions) for Monterrey Men Born Between 1940 and 1970

\begin{tabular}{|c|c|c|c|c|}
\hline & \multicolumn{2}{|c|}{ Manual } & \multicolumn{2}{|c|}{ Non-Manual } \\
\hline & Coeff. & S.E. & Coeff. & S.E. \\
\hline \multicolumn{5}{|l|}{ Age of Entry (Log of baseline rate) } \\
\hline Age $12-15$ & $-7.462 * * *$ & $(0.363)$ & $-7.444 * * *$ & $(0.290)$ \\
\hline Age $16-18$ & $-6.281 * * *$ & $(0.384)$ & $-6.112 * * *$ & $(0.354)$ \\
\hline Age 19-21 & $-5.571 * * *$ & $(0.402)$ & $-5.325 * * *$ & $(0.375)$ \\
\hline Age $>21$ & $-6.325 * * *$ & $(0.441)$ & $-4.753 * * *$ & $(0.389)$ \\
\hline \multicolumn{5}{|l|}{ Birth Cohort } \\
\hline 1940-1954 & ------ & ------ & ------ & ------ \\
\hline $1955-1964$ & -0.020 & $(0.118)$ & -0.058 & $(0.133)$ \\
\hline $1965-1970$ & $-0.324 *$ & $(0.189)$ & -0.279 & $(0.191)$ \\
\hline \multicolumn{5}{|l|}{ Short-Term Economic Conditions } \\
\hline (time-varying covariate) & $-0.111 * *$ & $(0.057)$ & -0.027 & $(0.053)$ \\
\hline \multicolumn{5}{|l|}{ Father's Death } \\
\hline (time-varying covariate) & 0.302 & $(0.197)$ & 0.055 & $(0.221)$ \\
\hline \multicolumn{5}{|l|}{ Migration Status } \\
\hline Natives & ------ & ------ & ------ & ------ \\
\hline Migrants from Rural Communities & $0.385 * *$ & $(0.165)$ & 0.287 & $(0.241)$ \\
\hline Migrants from Urban Communities & $0.309 *$ & $(0.172)$ & $0.489 * *$ & $(0.202)$ \\
\hline \multicolumn{5}{|l|}{ Father's Occupation } \\
\hline Higher Non-Manual & ------ & ------ & ------ & ------ \\
\hline Lower Non-Manual & $0.896 * *$ & $(0.359)$ & -0.068 & $(0.164)$ \\
\hline Higher Manual & $1.661 * * *$ & $(0.349)$ & -0.032 & $(0.181)$ \\
\hline Lower Manual & $1.554 * * *$ & $(0.349)$ & -0.114 & $(0.181)$ \\
\hline \multicolumn{5}{|l|}{ Educational Level (time-varying covariate) } \\
\hline Less than Primary completed & ------ & ------ & ------ & ------ \\
\hline Primary completed & $0.259 *$ & $(0.149)$ & $0.545 *$ & $(0.286)$ \\
\hline Secondary completed & -0.076 & $(0.188)$ & $0.545 *$ & $(0.323)$ \\
\hline Preparatory completed & -0.341 & $(0.279)$ & $0.879 * *$ & $(0.368)$ \\
\hline First year of College & $-1.540 * * *$ & $(0.371)$ & $0.927 * * *$ & $(0.351)$ \\
\hline $\begin{array}{l}\text { Attendance to School } \\
\text { (time-varying covariate) }\end{array}$ & $1.095 * * *$ & $(0.116)$ & $0.767 * * *$ & $(0.137)$ \\
\hline \multicolumn{5}{|l|}{ Number of Cases $=733$} \\
\hline \multicolumn{5}{|l|}{ Transitions to Manual Positions $=336$} \\
\hline \multicolumn{5}{|l|}{ Transitions to Non-Manual Positions $=397$} \\
\hline \multicolumn{5}{|l|}{ Chi square (vs. baseline model) $=322.10$} \\
\hline$* \mathrm{p}<0.1, * * \mathrm{p}<0.05, * * * \mathrm{p}<0.01$ & & & & \\
\hline
\end{tabular}




\begin{tabular}{|c|c|c|c|}
\hline & Manual & Non-Manual & Total \\
\hline Total Number of Job Spells & 2163 & 2113 & 4276 \\
\hline Average Num. Of Job Spells per Individual & ----- & ----- & 3.66 \\
\hline \multicolumn{4}{|l|}{ Distribution by Destination } \\
\hline Non-Manual Position & 15.1 & 55.8 & 35.3 \\
\hline Manual Position & 52.4 & 9.3 & 31.1 \\
\hline Out of the Labor Force & 13.0 & 9.9 & 11.5 \\
\hline Right-censored & 19.5 & 25.0 & 22.3 \\
\hline Average Years of Labor Force Experience & 8.8 & 8.6 & 8.7 \\
\hline \multicolumn{4}{|l|}{ Father's Occupation } \\
\hline Higher Non-Manual & 1.3 & 14.0 & 7.6 \\
\hline Lower Non-Manual & 11.6 & 29.3 & 20.4 \\
\hline Higher Manual & 25.3 & 22.3 & 23.8 \\
\hline Lower Manual & 61.8 & 34.4 & 48.3 \\
\hline \multicolumn{4}{|l|}{ Migration Status } \\
\hline Natives & 50.0 & 62.0 & 55.9 \\
\hline Rural Migrants & 31.3 & 16.1 & 23.8 \\
\hline Urban Migrants & 18.7 & 21.9 & 20.3 \\
\hline \multicolumn{4}{|l|}{ Educational Level } \\
\hline Less than Primary & 23.0 & 4.4 & 13.8 \\
\hline Primary completed & 33.9 & 11.0 & 22.6 \\
\hline Secondary completed & 29.5 & 18.7 & 24.1 \\
\hline Preparatory completed & 8.7 & 12.8 & 10.8 \\
\hline First year of College & 4.9 & 53.2 & 28.8 \\
\hline \multicolumn{4}{|l|}{ Type of Job } \\
\hline Formal & 60.8 & 80.9 & 70.8 \\
\hline Self-employee & 13.8 & 7.4 & 10.6 \\
\hline Unprotected employee & 25.5 & 11.7 & 18.6 \\
\hline \multicolumn{4}{|l|}{ Marital Status } \\
\hline Single & 59.8 & 54.8 & 57.3 \\
\hline Married & 40.2 & 45.2 & 42.7 \\
\hline
\end{tabular}

* All the figures represent column percents, except when specified

Source: EMOC-MTY Survey 
Table 7. Unadjusted Estimates of Multiple-destination Models for Job Shifts, Monterrey Men Born Between 1940 and 1970

\begin{tabular}{|c|c|c|c|c|c|c|}
\hline \multirow[b]{3}{*}{ Years of LF Experience } & \multicolumn{3}{|c|}{ Mobility from Manual Positions } & \multicolumn{3}{|c|}{ Mobility from Non-Manual Positions } \\
\hline & Non-Manual & Manual & Out & Non-Manual & Manual & Out \\
\hline & $-0.145 * * *$ & $-0.034 * * *$ & $-0.055 * * *$ & $-0.043 * * *$ & -0.014 & $-0.086 *$ \\
\hline Number of Previous Jobs & $-0.837 * * *$ & $-0.120 * *$ & $-0.358 * * *$ & $-0.227 * * *$ & 0.076 & -0.202 \\
\hline \multicolumn{7}{|l|}{ Type of Job } \\
\hline Self-employee & $-1.687 * * *$ & $-0.761 * * *$ & 0.045 & $-2.037 * * *$ & -0.500 & -0.479 \\
\hline Unprotected employee & -0.036 & $0.206 *$ & $0.354 *$ & -0.006 & $0.678 * * *$ & $1.206 * * *$ \\
\hline \multicolumn{6}{|l|}{ Short Term Economic } & -0.049 \\
\hline Period (tv) & $-0.547 * *$ & -0.179 & $-0.545 * *$ & 0.1502 & $-0.7219 * * *$ & -0.1515 \\
\hline \multicolumn{7}{|l|}{ Marital Status (tv) } \\
\hline Married & $-0.673 * * *$ & $-0.393 * * *$ & $-1.084 * * *$ & -0.157 & -0.336 & -0.366 \\
\hline \multicolumn{7}{|l|}{ Migration Status } \\
\hline Rural Migrants & $-1.110 * * *$ & $-0.247 * *$ & $-0.586 * * *$ & -0.269 & $0.537 *$ & -0.416 \\
\hline Urban Migrants & -0.349 & -0.110 & -0.367 & -0.180 & -0.195 & -0.345 \\
\hline \multicolumn{7}{|l|}{ Father's Occupation } \\
\hline \multicolumn{7}{|l|}{ Higher Non-Manual } \\
\hline Lower Non-Manual & -0.464 & -0.232 & -0.344 & $-0.394 * *$ & $2.056 * *$ & -0.340 \\
\hline Higher Manual & $-1.194 * *$ & 0.226 & -0.506 & -0.170 & $2.850 * * *$ & 0.489 \\
\hline Lower Manual & $-1.556 * * *$ & 0.071 & -0.951 & $-0.277 *$ & $2.829 * * *$ & -0.067 \\
\hline \multicolumn{7}{|l|}{ Educational Level (tv) } \\
\hline \multicolumn{7}{|l|}{ Less than Primary } \\
\hline Primary completed & 0.465 & $0.326 *$ & 0.139 & 0.758 & $-0.718 *$ & 0.506 \\
\hline Secondary completed & $1.306 * * *$ & $0.442 *$ & $0.454 *$ & $0.845 *$ & $-0.746 * *$ & 0.039 \\
\hline Preparatory completed & $1.469 * * *$ & -0.053 & $0.941 * * *$ & $0.862 *$ & $-2.459 * * *$ & -0.365 \\
\hline First year of College & $2.676 * * *$ & 0.272 & $1.399 * * *$ & $1.351 * * *$ & $-3.174 * * *$ & -0.103 \\
\hline$* \mathrm{p}<0.1, * * \mathrm{p}<0.05, * * * \mathrm{p}<$ & & & & & & \\
\hline
\end{tabular}


Table 8. Multivariate Multiple-destination Models for Job Shifts, Monterrey Men Born Between 1940 and 1970

\begin{tabular}{|c|c|c|c|c|c|c|}
\hline & \multicolumn{3}{|c|}{ Mobility from Manual Positions } & \multicolumn{3}{|c|}{ "Mobility from Non-Manual Positions } \\
\hline & Non-Manual & Manual & Out & Non-Manual & Manual & Out \\
\hline Years of LF Experience & $-0.108 * *$ & $-0.038 * * *$ & -0.011 & -0.0192 & -0.054 & $-0.1404 *$ \\
\hline Number of Previous Jobs & -0.070 & $0.173 * *$ & -0.051 & -0.0743 & 0.0877 & 0.3031 \\
\hline \multicolumn{7}{|l|}{ Type of Job } \\
\hline Self-employee & $-1.121 * *$ & $-0.687 * * *$ & 0.315 & $-1.8887 * * *$ & -0.6278 & -0.4021 \\
\hline Unprotected employee & 0.025 & 0.181 & $0.355 *$ & 0.1623 & 0.072 & $1.3379 * * *$ \\
\hline \multicolumn{5}{|l|}{ Short-Term Economic } & 0.0035 & -0.1066 \\
\hline Period (tv) & 0.043 & -0.159 & $-0.508 *$ & 0.126 & 0.1628 & 0.1153 \\
\hline \multicolumn{7}{|l|}{ Marital Status (tv) } \\
\hline Married & 0.020 & -0.213 & $-0.721 * *$ & -0.0327 & 0.1285 & 0.2189 \\
\hline \multicolumn{7}{|l|}{ Migration Status } \\
\hline Rural Migrants & -0.009 & -0.013 & 0.128 & 0.0572 & 0.3723 & -0.0796 \\
\hline Urban Migrants & 0.397 & 0.016 & 0.128 & 0.1626 & -0.0519 & 0.0639 \\
\hline \multicolumn{7}{|l|}{ Father's Occupation } \\
\hline \multicolumn{7}{|l|}{ Higher Non-Manual } \\
\hline Lower Non-Manual & $-1.025 *$ & -0.217 & -0.443 & -0.2431 & 1.3142 & -0.3851 \\
\hline Higher Manual & $-1.563 * * *$ & 0.226 & -0.492 & 0.0864 & $1.8298 *$ & 0.5442 \\
\hline Lower Manual & $-1.425 * *$ & 0.284 & -0.693 & -0.0891 & $1.706 *$ & 0.0209 \\
\hline \multicolumn{7}{|l|}{ Educational Level (tv) } \\
\hline \multicolumn{7}{|l|}{ Less than Primary } \\
\hline Primary completed & 0.297 & $0.289 * *$ & -0.004 & 0.649 & $-0.6804 *$ & 0.8731 \\
\hline Secondary completed & $0.839 * *$ & 0.250 & 0.257 & 0.5807 & $-0.8221 * *$ & 0.1807 \\
\hline Preparatory completed & $1.038 * * *$ & -0.227 & $0.878 * * *$ & $0.8281 *$ & $-2.4662 * * *$ & 0.1529 \\
\hline First year of College & $1.922 * * *$ & 0.165 & $1.115 * * *$ & $1.1275 * *$ & $-2.9782 * * *$ & 0.4706 \\
\hline Cases & & 2163 & & & 2113 & \\
\hline Number of transitions & 327 & 1132 & 283 & 1179 & 196 & 209 \\
\hline Model Chi Square & & 236.48 & & & 212.55 & \\
\hline
\end{tabular}

$* \mathrm{p}<0.1, * * \mathrm{p}<0.05, * * * \mathrm{p}<0.01$

Source: EMOC-MTY Survey 
Figure 1. Scheme for the Analysis of Occupational Mobility

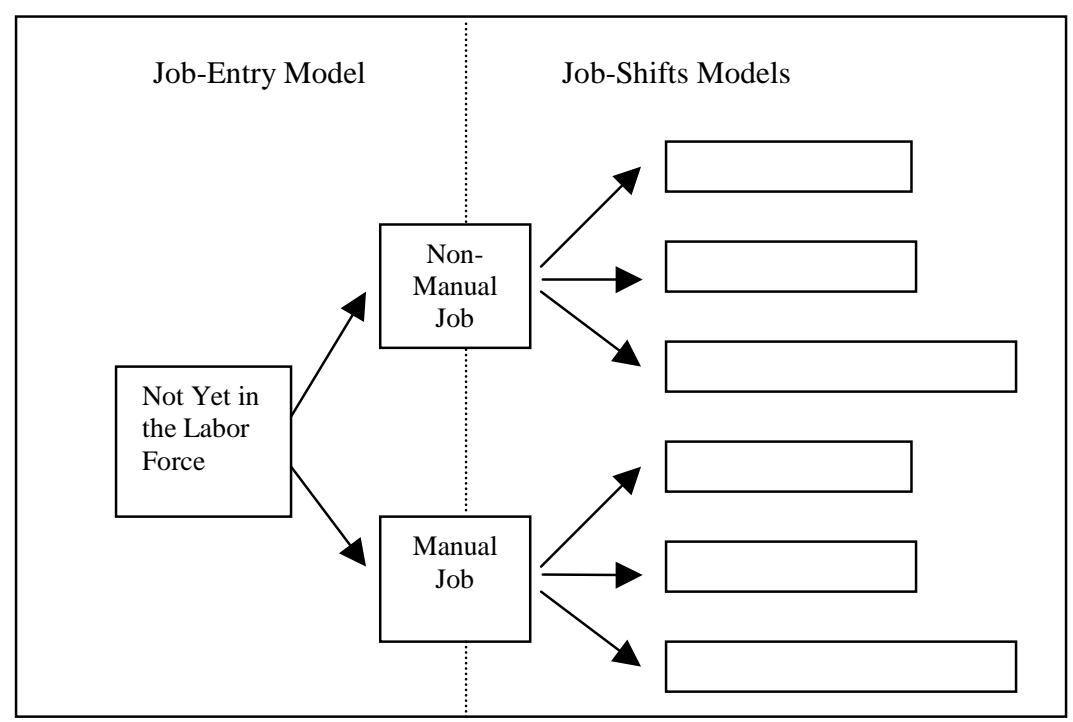


Figure 2. Index of Short-Term Economic Conditions in Mexico, 1950-2000*

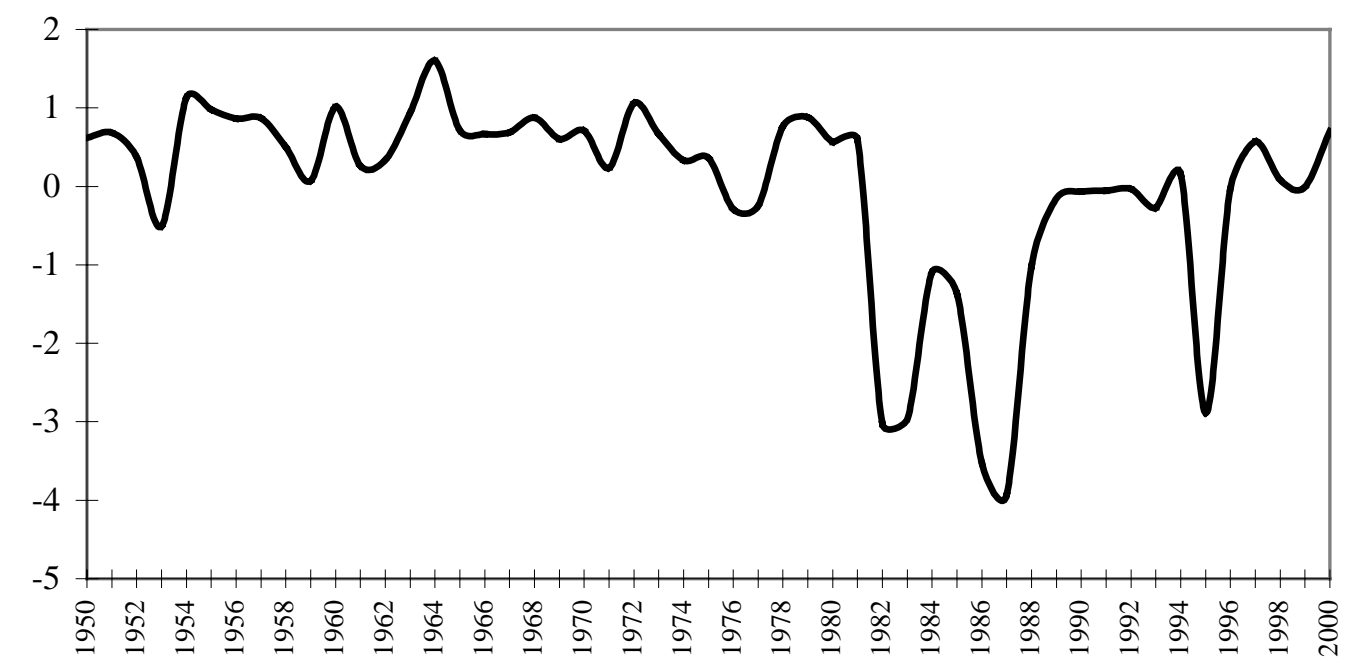

* See article for further details 
Figure 3. Simulated Cumulative Proportions of Men Entering into the Labor Force in Manual and Non-manual Positions, by Father's Occupation*

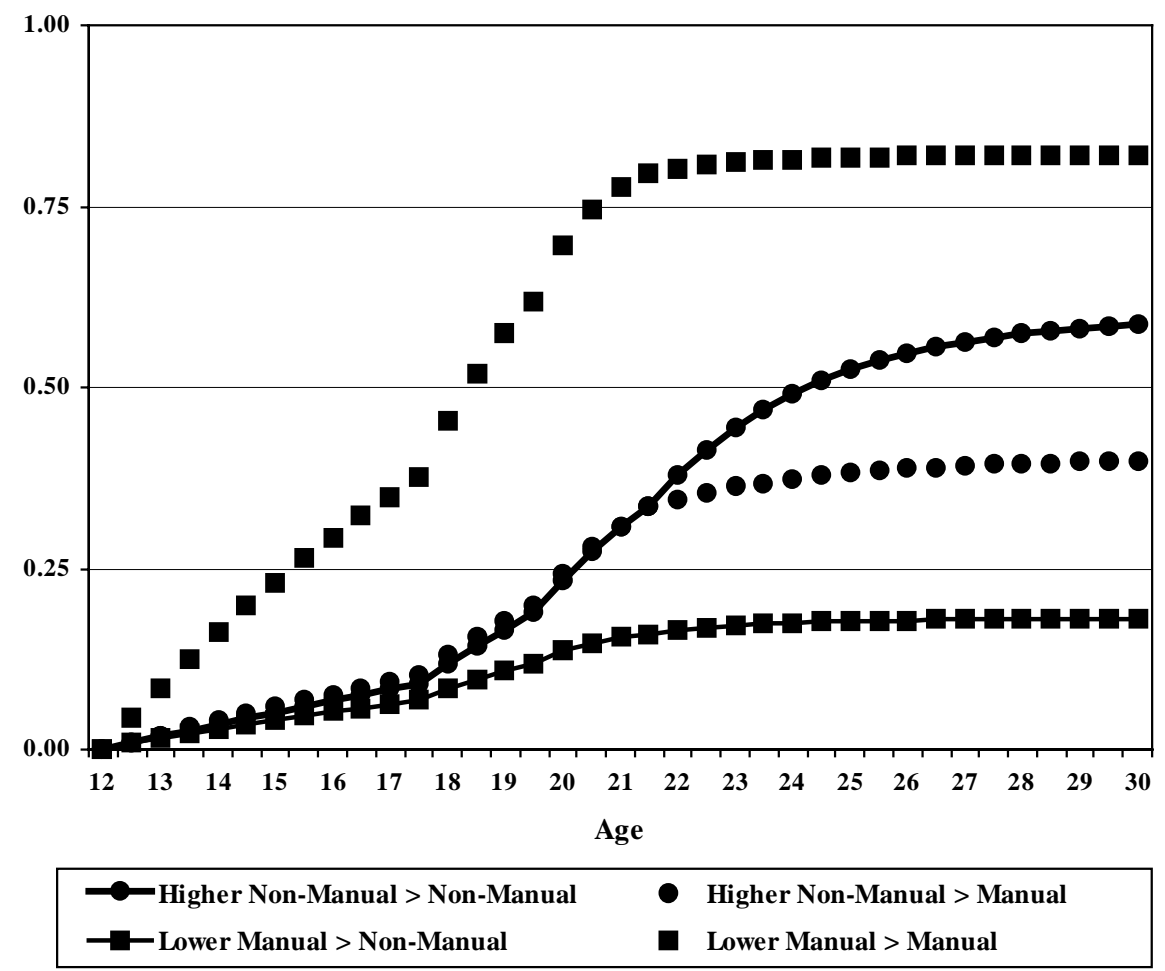

* These simulations are based on the model coefficients of Table 5. 